Research Article

\title{
Evaluation of hepatoprotective activity of aqueous extract of ricinus communis in Wistar rats
}

\author{
A. Naveen ${ }^{1}$, Shankar J. ${ }^{2}$, Premendran John ${ }^{1}$, N. Venkatanarayana ${ }^{1}$
}

\begin{abstract}
${ }^{1}$ Department of Pharmacology, Mamata Medical College, Khammam, Telangana, India ${ }^{2}$ Microtherapeutic Research Labs Pvt Ltd., Chromepet, Chennai, Tamilnadu, India
\end{abstract}

Received: 12 October 2015

Revised: 16 November 2015

Accepted: 18 December 2016

\section{*Correspondence to:}

A. Naveen,

Email: naveenalasyam@ gmail.com

Copyright: (C) the author(s), publisher and licensee Medip Academy. This is an openaccess article distributed under the terms of the Creative Commons Attribution NonCommercial License, which permits unrestricted noncommercial use, distribution, and reproduction in any medium, provided the original work is properly cited.

\begin{abstract}
Background: The aim of the present study was to evaluate hepatoprotective activity of aqueous extract of ricinus communis in wistar rats.

Methods: Liver, the key organ of metabolism and excretion, is constantly endowed with the task of detoxification of xenobiotics, environmental pollutants and chemotherapeutic agents. The animals were divided into six groups with six rats in each group. First group were taken as control, and they received $0.9 \%$ normal saline $10 \mathrm{ml} / \mathrm{kg}$ body weight orally. Second group was taken as CCl4 control group and treated with normal saline $(10 \mathrm{ml} / \mathrm{kg}$, p.o.) and CCl4: olive oil $(1: 1,2 \mathrm{ml} / \mathrm{kg}$, i.p. on 2, 5 and 8th day) daily for 20 day. The third group of six rats were treated with Liv 52- $100 \mathrm{mg} / \mathrm{kg}$ orally and CCl4: olive oil (1:1, $2 \mathrm{ml} / \mathrm{kg}$, i.p. on 2, 5 and 8th day) for 20 days .The fourth and fifth groups were taken as test groups and they received crude extract of ricinus communis orally once daily for 20 days at the dosage of 250 and $500 \mathrm{mg} / \mathrm{kg}$ respectively. CCl4: olive oil was given i.p on 2, 5 and 8th day. On the 21stday, blood samples were collected by cardiac puncture method. The blood samples were used estimate biochemical parameters like serum AST and ALT.

Results: It was found that the ricinus communis at the doses of 250 and $500 \mathrm{mg} / \mathrm{kg}$ exhibited moderate protective effect by lowering the serum levels of ALT and AST $(\mathrm{P}<0.001)$.
\end{abstract}

Conclusions: Ricinus communis has dose dependant hepatoprotective activity.

Keywords: Carbon tetrachloride, Hepatoprotective activity, Ricinus communis

\section{INTRODUCTION}

Plants have been used to treat diseases such as diabetes, jaundices, cardiovascular diseases, heavy metal poisoning, congestion of abdominal and pelvic cavities and scarlet fever. ${ }^{1}$ It is estimated that out of 250,000 to 500,000 species of plants only 1 to $2 \%$ of the terrestrial plants have been reasonably well investigated. Although today the synthetic drugs are larger in their number than the natural ones but still many synthetic drugs have their origin in the natural source and have been derived from plants and animals. ${ }^{2}$

Liver, the key organ of metabolism and excretion, is constantly endowed with the task of detoxification of xenobiotics, environmental pollutants and chemotherapeutic agents. ${ }^{3}$ Therefore, damage to the liver inflicted by hepatotoxic agents is of grave consequence. As such liver is highly affected primarily by toxic agents such as $\mathrm{CCl}_{4}$, paracetamol, D-galactosamine, alcohol, rifampicin and thioacetamide through different mechanisms. ${ }^{4}$

The castor oil plant, Ricinus communis, is a species of flowering plant in the spurge family, Euphorbiaceae. ${ }^{5}$ Methanolic extract of leaves is supposed to have antimicrobial property. ${ }^{6}$ Water extract of root-bark has showed some analgesic activity in rats. ${ }^{7}$ It also has antiinflammatory and anti-histaminic properties. ${ }^{8}$ Very Based on the above medicinal properties, the present study has been undertaken to investigate the hepatoprotective activity of aqueous extract of leaves of Ricinus communis against $\mathrm{CCl}_{4}$ induced hepatic damage in rats. 


\section{METHODS}

\section{Animals selected for the study}

Animals: All the animals included in the study were procured from animal house of Mamata Medical College, Khammam. Laboratory breed wistar rats of either sex, weighing $100-200 \mathrm{gm}$ were used for the study. The animals were maintained under standard laboratory conditions at $27-29^{\circ} \mathrm{C}$. Experimental protocol has been approved by the institutional animal ethics committee.

\section{Drugs used in the study}

Carbon tetrachloride manufactured by Molychem and Tab. Liv 52 manufactured by The Himalaya Drug Company were used in the study.

\section{Extraction procedure}

The preparation of crude extract of leaves of Ricinus communis was done in Department of Pharmacology, Mamata Medical College, Khammam. The powdered leaves were extracted with distilled water by a process of continuous hot percolation process or Soxhlet extraction or Soxhelation or simple maceration.

\section{Experimental design}

Wistar rats of both sexes weighing between 100-200gm were used. Food was restricted 18 hours prior to the experiment, but free access to water was allowed. The animals were divided into six groups with six rats in each group. All the animals were hydrated orally with $10 \mathrm{ml} / \mathrm{kg}$ of $0.9 \%$ normal saline for 7 days.

First group of six rats were taken as control, and they received $0.9 \%$ normal saline $10 \mathrm{ml} / \mathrm{kg}$ body weight orally. Second group of six rats was taken as $\mathrm{CCl} 4$ control group and treated with normal saline $(10 \mathrm{ml} / \mathrm{kg}$, p.o.) daily for 20 days. $\mathrm{CCl}_{4}$ : olive oil $(1: 1,2 \mathrm{ml} / \mathrm{kg}$, i.p. $) 2^{\text {nd }}, 5^{\text {th }}$ and $8^{\text {th }}$ day, $30 \mathrm{~min}$ after administering of normal saline. The third group of six rats were treated with Liv 52100 $\mathrm{mg} / \mathrm{kg}$ orally for 20 days and Carbon tetrachloride diluted with olive oil was given intra-peritoneally $(1: 1,2 \mathrm{ml} / \mathrm{kg})$ on $2^{\text {nd }}, 5^{\text {th }}$ and $8^{\text {th }}$ day, 30 mins after the administration of the standard drug.

The fourth and fifth groups were taken as test groups and they received crude extract of Ricinus communis obtained in liquid form along with normal saline orally once daily for 20 days at the dosage of 250 and $500 \mathrm{mg} / \mathrm{kg}$ respectively. Carbon tetrachloride diluted with olive oil was given intra-peritoneally $(1: 1,2 \mathrm{ml} / \mathrm{kg})$ on $2^{\text {nd }}, 5^{\text {th }}$ and $8^{\text {th }}$ day, 30 mins after the administration of the test drug.

\section{Estimation of biochemical parameters}

On the $21^{\text {st }}$ day, all animals were anesthetized with mild ether and blood samples were collected by cardiac puncture method. The blood samples were collected separately from ventricle into sterilized dry centrifuge a tube which was heparinised. The clear serum was separated at $2000 \mathrm{rpm}$ for $15 \mathrm{~min}$ and biochemical investigations were carried out to assess liver function Biochemical parameters like serum Aspartate aminotransferase (AST) and Alanine transaminase (ALT) were assayed by standard methods.

\section{Statistical analysis}

Analysis of the data was done using one way ANOVA and Turkey test. $\mathrm{P}$ values of less than 0.05 were considered significant.

\section{RESULTS}

\section{Aspartate aminotransferase (AST) levels}

The AST levels in blood sample of control group were $112 \pm 29.02$. The AST levels in blood sample of Standard group treated with $\mathrm{CCL}_{4}$ were $266.7 \pm 25.68$. The AST levels in blood sample treated with Liv 52 before CCL4 administration were $144.5 \pm 12.92$. The AST levels in blood sample of Group-IV were $179 \pm 21.59$. The AST levels in blood sample of Group-V were $161.7 \pm 11.92$. There was decrease in AST levels of animals treated with Liv-52, $250 \mathrm{mg}$, and 500mg of test drug as shown in Table 1 and Figure 1 which is significant when compared to standard. There is significant decrease in AST levels with $500 \mathrm{mg}$ of test drug as shown in Table 1 and Figure 1 which is comparable to decrease in AST levels withLiv52 .

Table 1: Effect of aqueous extract of Ricinus communis leaves on aspartate aminotransferase (AST) level in rats with CCl4 induced hepatotoxicity.

\begin{tabular}{|lll|}
\hline Groups (n=6) & Treatment & AST levels \\
\hline $\begin{array}{l}\text { Group-I } \\
\text { (control) }\end{array}$ & $\mathrm{NS} 10 \mathrm{ml} / \mathrm{kg}$ & $112 \pm 29.02$ \\
\hline $\begin{array}{l}\text { Group-II } \\
\text { (standard) }\end{array}$ & $\mathrm{CCl}_{4} 1 \mathrm{mg} / \mathrm{kg}$ & $266.7 \pm 25.68$ \\
\hline Group-III & $\begin{array}{l}\mathrm{CCl}_{4} 1 \mathrm{mg} / \mathrm{kg}+\mathrm{Liv} \\
52100 \mathrm{mg} / \mathrm{kg}\end{array}$ & $144.5 \pm 12.92$ \\
\hline $\begin{array}{l}\text { Group-IV } \\
\text { (test-I) }\end{array}$ & $\mathrm{CCl}_{4} 1 \mathrm{mg} / \mathrm{kg}+$ \\
\hline $\begin{array}{l}\text { Group-V } \\
\text { (test-II) }\end{array}$ & $\mathrm{CERCL}_{4} 1 \mathrm{mg} / \mathrm{kg}+$ & $179 \pm 21.59 *$ \\
\hline
\end{tabular}

AERCL $=$ Aqueous extract of Ricinus communis Leaves, $\mathrm{CCL}_{4}$ $=$ Carbon tetrachloride All the values are represented as Mean \pm SEM. $* \mathrm{P}<0.001$

\section{Alanine transaminase (ALT) levels}

The ALT levels in blood sample of control group were $27.17 \pm 2.949$. The ALT levels in blood sample of Standard group treated with $\mathrm{CCL}_{4}$ were $86.67 \pm 4.47$. The ALT levels in blood sample treated with Liv 52 before CCL4 administration were $30.67 \pm 3.565$. The ALT 
levels in blood sample of Group-IV were $45 \pm 3.992$. The ALT levels in blood sample of Group-V were $42 \pm 2.828$. There was decrease in ALT levels of animals treated with Liv-52, $250 \mathrm{mg}$ and 500mg as shown in Table 2 and Figure 2 which is significant when compared to standard. There is significant decrease in ALT levels with $400 \mathrm{mg}$ of test drug as shown in Table 2 and Figure 2 which is comparable to decrease in ALT levels with Liv-52.

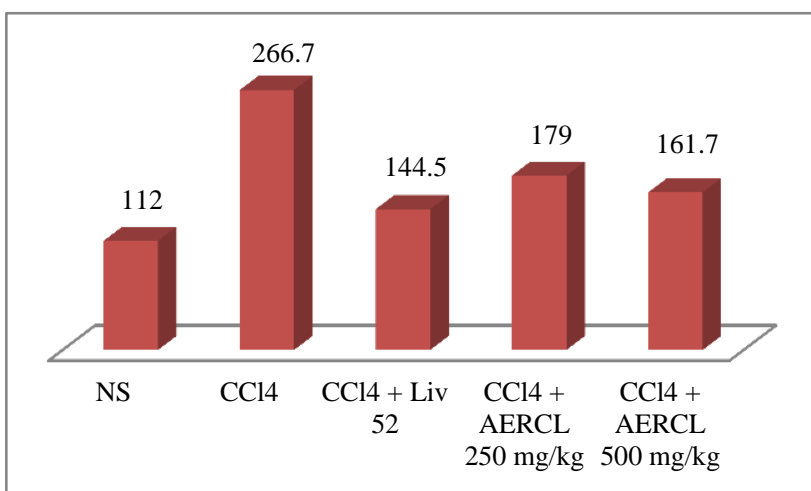

NS - Normal saline, CCl4 - Carbon tetrachloride, AERCL Aqueous extract of Ricinus Communis Leaves. For all observations $n=6$

Figure 1: The dose dependent effect of test drug on AST levels in rats.

Table 2: Effect of aqueous extract of Ricinus communis leaves on alanine transaminase (ALT) level in wistar rats with $\mathrm{CCl}_{4}$ induced hepatotoxicity.

\begin{tabular}{|lll|}
\hline Groups (n=6) & Treatment & AST levels \\
\hline $\begin{array}{l}\text { Group-I } \\
\text { (control) }\end{array}$ & $\mathrm{NS} 10 \mathrm{ml} / \mathrm{kg}$ & $27.17 \pm 2.949$ \\
\hline $\begin{array}{l}\text { Group-II } \\
\text { (standard) }\end{array}$ & $\mathrm{CCl}_{4} 1 \mathrm{mg} / \mathrm{kg}$ & $86.67 \pm 4.47$ \\
\hline Group-III & $\begin{array}{l}\mathrm{CCl}_{4} 1 \mathrm{mg} / \mathrm{kg}+\mathrm{Liv} \\
52100 \mathrm{mg} / \mathrm{kg}\end{array}$ & $30.67 \pm 3.565$ \\
\hline $\begin{array}{l}\text { Group-IV } \\
\text { (test-I) }\end{array}$ & $\begin{array}{l}\mathrm{CCl}_{4} 1 \mathrm{mg} / \mathrm{kg}+ \\
\mathrm{AERCL} 250 \mathrm{mg} / \mathrm{kg}\end{array}$ & $45 \pm 3.992$ \\
\hline $\begin{array}{l}\text { Group-V } \\
\text { (test-II) }\end{array}$ & $\begin{array}{l}\mathrm{CCl} \\
4\end{array} \mathrm{AERCL} 500 \mathrm{mg} / \mathrm{kg} / \mathrm{kg}$ & $42 \pm 2.828$ \\
\hline
\end{tabular}

$\mathrm{AERCL}=$ Aqueous extract of Ricinus communis Leaves, $\mathrm{CCL}_{4}$ $=$ Carbon tetrachloride. All the values are represented as Mean \pm SEM. $* \mathrm{P}<0.001$

\section{DISCUSSION}

One of the most commonly used chemical agents for liver damage in hepatoprotective study is $\mathrm{CCL}_{4}{ }^{9}$ The extent of hepatic damage was assessed by the elevated levels of serum marker enzyme AST and ALT which was significantly lowered by the extract administration of Ricinus communis in the tested groups of rats showing its hepatoprotective potential. It has been shown that administration of $\mathrm{CCL}_{4}$ lowers the total protein levels and it is presumed that after treatment with Ricinus communis extract the protein levels may be significantly elevated indicating its protective role against liver cell damage. ${ }^{10}$

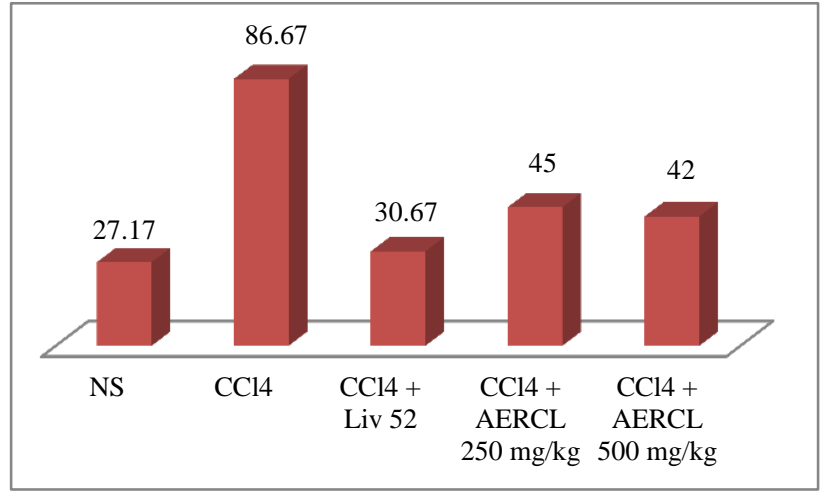

NS - Normal saline, CCl4 - Carbon tetrachloride, AERCL Aqueous extract of Ricinus Communis Leaves. For all observations $n=6$

\section{Figure 2: The dose dependent effect of test drug on} ALT levels in rats.

In hepatoprotective study, these phytoconstituents play a vital role in inducing microsomal enzymes, thereby accelerating the excretion of $\mathrm{CCl}_{4}$, or inhibiting the lipid peroxidation induced by $\mathrm{CCl}_{4}{ }^{11}$

It has been reported that fractionation of aqueous extract of Ricinus communis leaves and subsequent chromatographic fractionation and testing in the galactosamine model lead to isolation of two active fractions which in turn yielded two-pure compounds: ${ }^{12}$ ricinine, N-Demethyl-ricinine. N-Demethyl-ricinine was found to be more active and it reversed the biochemical changes produced by galactosamine induced hepatotoxicity.

As our study also provides a proof of hepatoprotective effect of Ricinus communis leaf extract, it is presumed that the mechanism of action and phytochemical substance are the same has reported. ${ }^{12}$

\section{CONCLUSION}

It is observed that there was significant decrease in 2 parameters (AST, ALT) at 250 and $500 \mathrm{mg} / \mathrm{kg}$ dose of Ricinus communis leaf extract. The present study has demonstrated that the aqueous extract of Ricinus communis has hepatoprotective effect against $\mathrm{CCl}_{4}$ induced hepatotoxicity in rats. Thus, this result suggests that the ricinine, N-Demethyl-ricinine present in Ricinus communis aqueous extract might efficiently increase the regenerative and reparative capacity of the liver. Although Ricinus communis aqueous extract has comparable hepatoprotective effect with Liv-52 in our study, clarification of the hepatoprotective mechanism and the active components of the Ricinus communis extract need further investigation. ${ }^{13}$

Funding: No funding sources

Conflict of interest: None declared

Ethical approval: The study was approved by the Institutional Ethics Committee 


\section{REFERENCES}

1. Said HM. Medicinal Herbal. Karachi: Baital Hikmah at Madinatal-Hikmah. 1996:215-17.

2. Philipson JD. Natural products as a basis for new drugs Trends. Pharmacol. Sci. 1989;1:36-8.

3. Singh S, Mehta A, Mehta P. Hepato protective Activity of Cajanus cajana Against Carbon Tetrachloride Induced Liver Damage. International Journal of Pharmacy And Pharmaceutical Sciences. 2011;3(2):146-7.

4. Gond. Hepatoprotective Activity of Ficus carica Leaf Extract, Indian J Pharm Sci. 2008;70(3):364-6.

5. Euphorbiaceae (spurge) genomics. Institute for Genome Sciences. University of Maryland Medical School. Retrieved. 2009;3:9.

6. Oyewole OI, Owoseni AA, Faboro EO. Studies on medicinal and toxicological properties of Cajanus cajan, Ricinus communis and Thymus vulgaris leaf extracts. Journal of Medicinal Plant Research. 2010;4(19):2004-8.

7. Williamson EM. (ed) Major Herbs of Ayurveda Churchill Livingstone. 2002.

8. Lomash V, Parihar SK, Jain NK, Katiyar AK. Effect of Solanum nigrum and Ricinus communis extracts on histamine and carrageenan-induced inflammation in the chicken skin. Cellular and molecular biology (Noisy-le-Grand, France). 2010;56:1239-51.
9. Johnston DE, Kroening C. Mechanism of early carbon tetrachloride toxicity in cultured rat hepatocytes. Pharmacol Toxicol. 1998;83(6):231-9.

10. Singh S, Mehta A, Mehta P. Hepato protective activity of Cajanus cajana carbon tetrachloride induced liver damage. International journal of pharmacy and pharmaceutical sciences. 2011;3(2):146-7.

11. Mehta RS, Shankar MB, Geetha M, Saluja AK. Hepato protective activity of Trianthema portulacastrum. Indian drugs. 1999;36(4):241-3.

12. Vesen PKS, Shukla B, Patnayak GK, Tripathi SC. Hepato protective activity of Ricinus communis leaves. Pharmaceutical Biology. 1992;30(4):241-50.

13. Princea ES, Parameswarib P, Khan RM. Protective effect of Ricinus communis leaves extract on carbon tetrachloride induced hepatotoxicity in albino rats. Iranian Journal of Pharmaceutical Sciences. 2011;7(4):269-7.

Cite this article as: Naveen A, Shankar J, John P, Venkatanarayana N. Evaluation of hepatoprotective activity of aqueous extract of ricinus communis in Wistar rats. Int J Basic Clin Pharmacol 2016;5:35861. 